\title{
Subject Reference Start Date Time
}

National Cancer Institute

\section{Source}

National Cancer Institute. Subject Reference Start Date Time. NCI Thesaurus. Code C83395.

The date and time a subject reference began. 